\title{
Pengaruh Manajemen Pengetahuan dan Komitmen Organisasional Terhadap Kinerja Dosen di Universitas Terbuka (Studi Terhadap Persepsi Dosen Universitas Terbuka)
}

\author{
Fikri Irawan Abdurahman ${ }^{1}$
}

\begin{abstract}
Abstrak
Berdasarkan hasil riset Majalah Tempo dan Globe Asia, Universitas Terbuka belum termasuk dalam kategori universitas terbaik di Indonesia. Hal tersebut menggambarkan bahwa kinerja Universitas Terbuka belum termasuk dalam kinerja perguruan tinggi yang unggul di Indonesia. Universitas Terbuka merupakan universitas yang menggunakan Sistem Pendidikan Jarak Jauh (SPJJ). Tujuan penelitian ini adalah untuk menganalisis manajemen pengetahuan, komitmen organisasional, dan kinerja dosen di Universitas Terbuka, serta untuk menganalisis seberapa besar pengaruh manajemen pengetahuan dan komitmen organisasional terhadap kinerja dosen di Universitas Terbuka, baik secara parsial maupun simultan.

Metode penelitian yang digunakan adalah deskriptif dan eksplanatori survei. Teknik pengambilan sampel menggunakan teknik simple random sampling (SRS). Instrumen penelitian menggunakan angket. Teknik analisis data menggunakan analisis regresi linear berganda dengan bantuan program SPSS 18.00 .

Berdasarkan hasil penelitian, dapat disimpulkan bahwa hubungan manajemen pengetahuan dan komitmen organisasional dengan kinerja dosen bersifat positif. Makna hubungan positif disini adalah jika manajemen pengetahuan dan komitmen organisasional meningkat, maka kinerja dosen juga akan meningkat secara positif. Manajemen pengetahuan dan komitmen organisasional berpengaruh positif dan signifikan terhadap kinerja dosen di UT, baik secara parsial maupun simultan.
\end{abstract}

\section{Kata Kunci : Kinerja Dosen, Komitmen Organisasional, Manajemen Pengetahuan}

\section{Pendahuluan}

Jembatan emas untuk mewujudkan sumber daya manusia yang berkualitas adalah pendidikan. Mengingat pentingnya peran pendidikan bagi kemajuan pembangunan sebuah bangsa, maka tidak rnengherankan kalau banyak negara memberikan prioritas pembangunan di sektor pendidikan ini (Kuncoro 2008;89). Menurut laporan World Education Forum (WEF) yang dipublikasikan pada bulan April tahun 2000, kemajuan pendidikan di dunia ini meningkat di semua tingkatan. Pertumbuhan siswa terjadi pada jenjang pendidikan dasar, mencapai 82 (delapan puluh dua) juta untuk siswa pria dan 44 (empat puluh empat) juta untuk siswa putri selama periode tahun 19901998. Hampir di semua negara-negara yang tergolong sebagai negara berkembang, jumlah siswa yang mendaftar di jenjang pendidikan dasar mencapai lebih dari 80\%, jumlah siswa yang drop out menurun, dan jumlah orang yang melek buta huruf meningkat.
Pendidikan tinggi merupakan salah satu pilar penting dalam pembangunan pendidikan. Menurut Yudo Husodo (2007) pada tahun 2005 anggaran belanja penyelenggaraan perguruan tinggi di seluruh dunia mencapai 300 miliar dollar AS, atau 1\% dari produk ekonomi dunia; sedangkan Indonesia baru mencapai 0,13 persen dari Product Domestic Brutto (PDB). Tahun 2006, biaya yang disediakan untuk tiap mahasiswa di Amerika Serikat adalah Rp. 200 juta per tahun, Jepang Rp. 108 juta per tahun, Eropa Rp. 81 juta per tahun, sementara Indonesia hanya Rp. 6 juta per mahasiswa per tahun.

Data statistik Direktorat Jenderal Pendidikan Tinggi Departemen Pendidikan Nasional (Depdiknas) mencatat bahwa secara kuantitas perkembang perguruan tinggi (akademi, politeknik, sekolah tinggi, institut dan versitas) di Indonesia meningkat tajam, jika pada bulan September 1999 jumlah lembaga pendidikan tinggi di Indonesia 
berjumlah 1.634 perguruan tinggi, kemudian jumlahnya naik menjadi 2.428 atau naik sebesar 49\% selama lima tahun terakhir (1999-2004).

Apabila jumlah lembaga pendidikan tinggi itu dibedakan menurut statusnya, maka jumlah Perguruan Tinggi Negeri (PTN) naik dari 77 menjadi 81 (atau naik sebesar 5,2\%) PTN, tahun 2006 menjadi 82 PTN dan Perguruan Tinggi Swasta (PTS) naik dari 1.557 menjadi 2.347 (atau naik sebesar 51,4\%) dalam periode waktu tersebut, bahkan pada tahun 2006 telah menjadi 2.679 PTS. Jumlah mahasiswa PTN pada tahun 2004 mencapai 880 ribu termasuk mahasiswa Universitas Terbuka, sementara jumlah mahasiswa PTS mencapai 1,7 juta. Angka partisipasi kasar mahasiswa telah meningkat dari 9\% pada tahun 1985 menjadi 12,8\% pada tahun 2002. Dibandingkan dengan negara-negara lain di dunia, angka partisipasi kasar pendidikan tinggi tahun 2002 masih tergolong rendah, bila dibandingkan dengan negara-negara di Asia Tenggara, misalnya Brunei 13,89\%, Malaysia 23,26\%, Filipina 29,45\%, dan Thailand 31,92\%.

Terdapat suatu gejala yang terjadi pada dunia pendidikan tinggi di Indonesia, yaitu penurunan jumlah minat masyarakat dalam menyekolahkan anaknya pada perguruan tinggi. Penurunan ini terjadi karena rendahnya tingkat kepercayaan masyarakat terhadap perguruan tinggi di Indonesia. Tingginya biaya pendidikan jika dikaitkan dengan pendapatan per kapita masyarakat dan tidak adanya jaminan kerja di dunia kerja menjadi faktor pendorong masyarakat untuk tidak menyekolankan anaknya pada perguruan tinggi (HU Kompas, 14 Oktober 2009).

Sebagai gambaran dalam pemetaan kualitas perguruan tinggi di Indonesia berdasarkan daya serap Iulusan di dunia kerja atau dunia industri, majalah Tempo pada tahun 2007 melakukan survei terhadap dunia industri atau dunia kerja. Hasil yang diperoleh berdasarkan penelitian tersebut, disajikan pada Tabel 1 di bawah ini:

\section{Tabel 1}

\section{Perguruan Tinggi Terbaik di Indonesia menurut Majalah Tempo}

\begin{tabular}{|c|l|}
\hline Ranking & \multicolumn{1}{|c|}{ Perguruan Tinggi } \\
\hline 1 & Universitas Indonesia \\
\hline 2 & Institut Teknologi Bandung \\
\hline 3 & Universitas Gadjah Mada \\
\hline
\end{tabular}

\begin{tabular}{|c|l|}
\hline Ranking & \multicolumn{1}{|c|}{ Perguruan Tinggi } \\
\hline 4 & Institut Pertanian Bogor \\
\hline 5 & Institut Teknologi Sepuluh November \\
\hline 6 & Universitas Airlangga \\
\hline 7 & Universitas Trisakti \\
\hline 8 & Universitas Padjajaran \\
\hline 9 & Universitas Atmajaya Jakarta \\
\hline 10 & Universitas Diponegoro \\
\hline 11 & Universitas Bina Nusantara \\
\hline
\end{tabular}

Sumber: Majalah Tempo Edisi 14-20 Mei 2007

Sementara itu, berdasarkan hasil survei yang dilaksanakan oleh Globe Asia (sebuah lembaga riset independen bersekala global) di tahun 2008 tentang perguruan tinggi terbaik di Indonesia dari segi kualitas lulusan serta bangunan fisik, diperoleh temuan sepeti disajkkan pada Tabel 2 berikut ini:

\section{Tabel 2}

\section{Perguruan Tinggi Terbaik di Indonesia menurut Globe Asia}

\begin{tabular}{|c|l|}
\hline Ranking & \multicolumn{1}{|c|}{ Perguruan Tinggi } \\
\hline 1 & Universitas Indonesia \\
\hline 2 & Universitas Pelita Harapan \\
\hline 3 & Universitas Gadjah Mada \\
\hline 4 & Institut Teknologi Bandung \\
\hline 5 & Institut Pertanian Bogor \\
\hline 6 & Universitas Padjajaran \\
\hline 7 & Universitas Airlangga \\
\hline 8 & Universitas Trisakti \\
\hline 9 & Universitas Hasanuddin \\
\hline 10 & Institut Teknologi 10 November Surabaya \\
\hline 11 & Universitas Diponegoro \\
\hline 12 & Universitas Atmajaya \\
\hline 13 & Universitas Tarumanegara \\
\hline 14 & Universitas Parahyangan \\
\hline 15 & Universitas Sumatera Utara \\
\hline 16 & Universitas Bina Nusantara \\
\hline 17 & Universitas Muhammadiyah Malang \\
\hline 18 & Universitas Maranatha \\
\hline 19 & Universitas Satya Wacana \\
\hline 20 & Universitas Petra \\
\hline
\end{tabular}

Sumber: Globe Asia, Februari 2008.

Berdasarkan hasil riset tersebut, kedua lembaga independen (Majalah Tempo dan Globe Asia) menginformasikan bahwa Universitas Terbuka (UT) belum 
termasuk dalam kategori universitas terbaik di Indonesia. Hal tersebut menggambarkan bahwa kinerja UT belum termasuk dalam kinerja perguruan tinggi yang unggul. Kondisi tersebut perlu segera diatasi dengan menyajikan sejumlah alternatif pilihan strategis yang akan digunakan dalam perancangan pengembangan organisasi UT kedepan agar mampu menjadi salah satu universitas di Indonesia yang memiliki keunggulan dan daya saing yang tinggi, salah satunya peningkatan kinerja dosen di Universitas Terbuka.

Saat ini, semua kawasan di dunia telah memiliki dan mengembangkan institusi-institusi pendidikan tinggi jarak jauh (PTJJ). Menurut Mohammad Imam Farisi dan Kisyani (2008:1), jika pada awalnya, sebagian dari institusi PTJJ tersebut hanya bersifat marginal, belakangan beberapa PTJJ telah berkembang pesat menjadi pusatpusat unggulan institusi PTJJ dan mega universitas di dunia. Setidaknya, Jung (2005) mencatat ada 11 mega universitas jarak jauh di seluruh dunia, yaitu: Allama Iqbal Open University (AIOU, Pakistan); Anadolu University (Anadolu, Turkey); China Central Radio and TV University (CCRTVU, China); Indira Gandhi National Open University (IGNOU, India); Universitas Terbuka (UT, Indonesia); Korea National Open University (KNOU, Korea); Payame Noor University (Iran); Sukhothai Thammathirat Open University (STOU, Thailand); Open University (OU, UK); University of South Africa (South Africa); dan Shanghi TV University (SHTVU, China).

Saat ini, UT memiliki empat fakultas dengan 35 program studi Diploma dan S-1 serta tiga program Magister, 117 mata kuliah melalui tutorial radio, 419 mata kuliah melalui tutorial online, 1.002 program tutorial televisi, dan 962 (30\%) bahan ajar dalam bentuk multimedia. Sejak tahun 2002 UT mulai mengembangkan layanan UT online berbasis ICT dan terus dikembangkan dari waktu ke waktu. Pada tahun 2005, UT menyediakan tutorial online untuk 377 mata kuliah, dan meningkat menjadi 419 mata kuliah pada tahun 2006. Mahasiswa yang mengakses tutorial online pada tahun 2005 sebanyak 5.225 orang, meningkat menjadi 16.243 orang tahun 2006. Selain itu, UT juga mengumumkan hasil ujian dan pembelian bahan ajar secara online (Suparman dan Zuhairi, 2007; UT, 2008). Mulai tahun 2008 ini UT berencana setahap demi setahap akan mewajibkan mahasiswa program S-1 untuk mengikuti tutorial online, sama dengan yang telah diterapkan kepada mahasiswa pascasarjana.

UT memiliki kantor regional sebanyak 37 Unit Program Belajar Jarak Jauh Universitas Terbuka (UPBJJUT yang tersebar di 33 provinsi seluruh Indonesia. Untuk mendukung kegiatan operasional, setiap UPBJJ-UT menjalin kerja sama dengan berbagai institusi, terutama dengan:

1. PTN (perguruan tinggi negeri ) dan perguruan tinggi swasta (PTS) setempat, terutama dalam penyediaan tutor, pembimbing praktik atau praktikum, dan pengawas ujian;

2. Pemerintah daerah setempat, baik dalam penyelenggaraan tutorial dan ujian maupun dalam mendapatkan beasiswa bagi mahasiswa UT.

3. Stasiun radio dan TV setempat untuk menyiarkan tutorial atau informasi kegiatan akademik. Tutorial yang disiarkan secara rutin melalui stasiun $R R /$.

(Info Pendidikan, Suplemen Harian Umum Media Indonesia, 2010:5)

Universitas Terbuka (UT) merupakan universitas yang menggunakan Sistem Pendidikan Jarak Jauh (SPJJ). Menurut Keegan (Any Meilani, 2010:2), salah satu karakteristik dari Pendidikan Tinggi Jarak Jauh (PTJJ) adalah keterpisahan antara pengajar dengan peserta didik. Keterpisahan secara fisik tersebut sering dianggap sebagai suatu bentuk kelemahan pendidikan jarak jauh, walaupun menurut Moore (Any Meilani, 2010:2) mengatakan bahwa pertemuan antar pengajar dan yang diajar, atau a meeting of mind masih terjadi walaupun tidak terjadi pertemuan secara fisik. Selain itu, menurut Soekartawi (Any Meilani, 2010:2) masalah-masalah yang lazim dialamatkan ke Pendidikan Jarak Jauh (PJJ) adalah masalah: a). kualitas pendidikan: b). kurang atau tidak adanya iteraksi antara dosen dan mahasiswa; c). mahasiswa tidak atau kurang mempunyai akses kepada teknologi yang dipakai dalam PJJ; d). tidak ada fasilitas teknologi atau pendukung PJJ lainnya; e). PJJ biayanya mahal dianggap mahal padahal pertemuan terbatas. Masalah-masalah tersebut seharusnya tidak perlu ada, apabila PJJ tersebut dilaksanakan dengan baik. Untuk mengurangi masalah-masalah tersebut, PJJ menggunakan berbagai macam media untuk memfasilitasi adanya keterpisahan antara pengajar dengan peserta didik. Oleh karena itu, pengembangan media pada pendidikan 
jarak jauh merupakan salah satu kegiatan yang perlu dilakukan secara berkesinambungan oleh institusi pendidikan jarak jauh untuk mencari berbagai kemungkinan media yang dapat diakses oleh mahasiswa.

PTJJ menghendaki terlaksananya suatu bentuk belajar mandiri yang direncanakan dengan baik dan diorganisasikan secara sistematik oleh institusi penyelenggaranya. Ini berarti bahwa proses belajar dan mengajar diselenggarakan oleh suatu tim pengajar yang bertanggung jawab dalam hal-hal yang terkait dengan keberhasilan belajar mahasiswa. Dalam PTJJ peran institusi menjadi sangat menonjol dalam perencanaan dan pengorganisasian pembelajaran. Seringkali dikatakan bahwa dalam institusi PTJJ bukan dosen yang melaksanakan proses pembelajaran dengan cara menyediakan dan mengantarkan sumber belajar kepada mahasiswa yang bertempat tinggal di berbagai daerah, dan menghendaki mahasiswa untuk datang ke kampus mengikuti perkuliahan tatap muka di dalam kelas. Mahasiswa dapat belajar dimana saja, kapan saja, belajar mandiri maupun.

kelompok, dan menggunakan berbagai media yang disediakan atau difasilitasi penyediaannya oleh institusi. Bantuan belajar, bimbingan serta supervisi yang dilakukan oleh tenaga pengajar dilakukan dengan cara tatap muka maupun cara jarak jauh dengan menggunakan media komunikasi yang dapat menggantikan peran pertemuan tatap muka sebagaimana dalam sistem pendidikan biasa. (Yasnimar llyas dan Amin Zuhairi, 2004:2-3).

Untuk menyelenggarakan program PTJJ diperlukan koordinasi, komunikasi serta dukungan pengelolaan yang terus menerus dan ketat karena luasnya jaringan kerja dan sebaran mahasiswa peserta program PTJJ. Dengan demikian kegiatan pembelajaran jarak jauh dapat diselenggarakan secara fleksibel bagi mahasiswa, serta dapat menjangkau mahasiswa dari berbagai lapisan sosial dan ekonomi yang tinggal di berbagai daerah perkotaan, pedesaan maupun daerah terpencil. Fleksibilitas dan daya jangkau bagi mahasiswa ini harus dapat disediakan dengan biaya yang terjangkau oleh mahasiswa pada umumnya. Mengingat sebaran geografi dan demografi peserta program PTJJ yang luas, salah satu kendala sistem PTJJ adalah sulitnya memperoleh umpan balik secara cepat terhadap permasalahan yang dihadapi dalam proses belajar mahasiswa, karena letak tempat tinggal mahasiswa yang terpencil dan secara geografis jauh dari institusi penyelenggaranya. Hal ini ini menjadi perhatian dan tantangan yang penting untuk diperhatikan. Jarak geografis tersebut dapat diatasi oleh sistem PTJJ melalui pemanfaatan berbagai macam media serta teknologi informasi dan komunikasi/TIK. (Yasnimar Ilyas dan Amin Zuhairi. 2004:3).

Berkenaan dengan uraian tersebut, terkait dengan kinerja dosen di UT yang biasa disebut dengan tutor, Any Meilani (2010:8) menyatakan bahwa dosen atau tutor diharuskan menulis 8 (delapan) inisiasi dan 3 (tiga) tugas yang akan dikirimkan melalui internet kepada mahasiswa peserta tutorial online untuk memulai berdiskusi. Selain itu, tutor harus menyediakan 8 (delapan) forum diskusi, tempat mahasiswa berinteraksi dengan tutor maupun dengan peserta tutorial lainnya. Materi inisiasi dapat berupa tinjauan pustaka, ringkasan, selayang pandang bagian-bagian penting materi matakuliah, latihan tambahan, simulasi ataupun pertanyaan-pertanyaan. Inisiasi tersebut diharapkan dapat memberikan motivasi belajar dan arahan atau strategi belajar bagi mahasiswa. Untuk menciptakan suasana seperti bertatap muka dengan dosennya, materi inisiasi yang pertama disarankan berisi ucapan selamat datang kepada mahasiswa yang telah bergabung, gambaran pelaksanaan tutorial matakuliah yang bersangkutan, peran yang diharapkan dari mahasiswa serta informasi tugas yang akan diberikan kepada mahasiswa.

Terkait dengan kinerja dosen atau tutor, hasil penelitian Any Meilani (2010:10-11) menemukan bahwa:

Sebanyak 75\% tutor tidak membuat Rancangan Aktivitas Tutorial (RAT) dan Matriks Aktivitas Tutorial (MAT) sebelum melaksanakan tutorial. Hal ini disebabkan karena sebagian tutor belum mengetahui cara membuat RAT dan MAT, selain itu program studi belum mengharuskan tutor untuk membuat RAT dan MAT tersebut. Idealnya tutor harus menyiapkan RAT dan MAT sebelum melaksanakan tutorial, karena RAT dan MAT tersebut merupakan acuan dalam melaksanakan tutorial. Materi inisiasi sudah disiapkan oleh 95\% tutor yang mengelola tutorial, dimana 50\% tutor menyiapkan 8 inisiasi, 20\% menyiapkan 7 inisiasi dan masing-masing 10\% menyiapkan 6, 5 dan 4 inisiasi. Selain itu, 90\% tutor telah menyiapkan tugas yang akan diberikan kepada mahasiswa, 
dimana 72\% tutor menyiapkan 3 tugas, 11\% tutor menyiapkan 2 tugas dan sisanya 17\% tutor menyiapkann 1 tugas. Forum diskusi atau tempat untuk mahasiswa mengajukan pertanyaan atau memberikan tanggapan atas materi yang diberikan dalam tutorial telah disiapkan oleh 65\% tutor, dimana 31\% tutor menyiapkan 8 forum diskusi, $8 \%$ tutor menyiapkan 4 forum diskusi, 45\% tutor menyiapkan 3 forum diskusi, dan sisanya 16\% tutor menyiapkan 2 forum diskusi. Ketidakseragaman penyiapan materi inisiasi, tugas dan forum diskusi tersebut sangat dipengaruhi oleh komitmen dan keaktifan tutor yang bersangkutan dalam mengelola tutorial. Pertanyaan yang diajukan mahasiswa selalu ditanggapi oleh 70\% tutor, sedangkan 30\% tutor tidak menanggapinya. Hal ini menunjukkan ada sebagian tutor yang belum memahami tugasnya sebagai tutor dalam mengelola tutorial. Padahal feedback dari tutor merupakan unsur yang sangat diharapkan oleh mahasiswa.

Berdasarkan hasil observasi dan pengamatan yang dilaksanakan dalam konteks penelitian pendahuluan di Tahun 2010, terhadap dosen atau tutor di UT, ditemukan beberapa masalah penting terkait dengan kinerja dosen di UT, antara lain:

1. Masih terdapat beberapa dosen atau tutor yang belum mentaati sepenuhnya peraturan pelaksanaan tutorial, sehingga sering kali pelaksanaan tutorial menjadi tidak efektif, bahkan terkesan hanya formalitas saja.

2. Banyaknya program institusi Univeristas Terbuka yang sudah disusun tetapi belum terlaksana dengan baik dikarenakan belum adanya dukungan yang optimal dari dosen atau tutor, misalnya bahan ajar yang aktual dan sesuai dengan kebutuhan mahasiswa.

3. Masih terdapat dosen atau tutor yang tidak bisa mengisi kelas, diganti dengan dosen atau tutor lain tanpa melalui mekanisme dan prosedur yang seharusnya, sehingga proses tutorial menjadi tidak efektif.

4. Masih terdapat dosen yang terlambat dalam menyampaikan hasil ujian akhir semester dan revisi terhadap nilai yang seharusnya diperoleh mahasiswa sehingga menghambat mahasiswa untuk mengetahui kemajuan hasil studinya.
Dalam konteks peningkatan kinerja dosen di UT, maka manajemen pengetahuan (knowledge management) sebagai penunjang dalam proses pendidikan yang berkualitas dan modern, serta komitmen organisasional dosen perlu untuk dioptimalkan, dimana kedua variabel tersebut (manajemen pengetahuan dan komitmen organisasional) diduga memberikan kontribusi terhadap naik turunnya kinerja dosen di Universitas Terbuka. Permasalahan tersebut, menyebabkan hambatan dalam perwujudan visi dan misi yang ditetapkan UT dalam Rencana Stratejik Universitas Terbuka (Renstra UT) Tahun 2010-2021, yaitu: "Pada tahun 2021, UT menjadi institusi PTTJJ berkualitas dunia dalam menghasilkan produk pendidikan tinggi dan dalam penyelenggaraan, pengembangan, dan penyebaran informasi PTTJJ".

UT menjadi institusi pendidikan terbuka jarak jauh (PTTJJ) berkualitas dunia mengandung makna bahwa penyelenggaraan UT telah memenuhi standar penyelenggaraan terbaik PTTJJ yang diakui, baik oleh komunitas maupun lembaga-lembaga atau asosiasi institusi $P T T J J$ dunia. Sebagai konsekuensi dan sesuai dengan prinsip sistem PTTJJ, UT juga menghasilkan berbagai produk pendidikan tinggi berkualitas tinggi yang terstandar. Pengertian produk pendidikan tinggi meliputi produk akademik yang secara substansi mengikuti perkembangan ilmu pengetahuan dan teknologi (IPTEK) dan tetap terjaga relevansinya dengan perkembangan masyarakat dan pembangunan nasional; serta lulusan yang kompetitif secara global. Pengertian terstandar adalah kualitas produk yang dijamin baku di setiap tempat penyelenggaraan PTTJJ oleh UT. Dalam konteks ini, maka implementasi manajemen pengetahuan di UT belum optimal, karena sebagai institusi pendidikan terbuka jarak jauh (PTTJJ), UT belum mampu menghasilkan produk manajemen pengetahuan yang berkualitas dan diakui oleh komunitas maupun lembaga-lembaga atau asosiasi institusi PTTJJ dunia.

Menurut Bergeron (2003:8):

"Knowledge management (KM) is a deliberate, systematic business optimization strategy that selects, distills, stores, organizes, packages, and communicates information essential to the business of a ccompany in a manner that improves employee performance and corporate competitiveness". 
Manajemen Pengetahuan adalah suatu strategi optimalisasi bisnis yang disengaja dan sistematis untuk memilih, menyaring, mengorganisasi, memaketkan, dan mengkomunikasikan informasi penting bagi bisnis perusahaan yang bertujuan untuk meningkatkan kinerja karyawan dan kemampuan kompetitif perusahaan.

Komitmen organisasional adalah kerelaan untuk bekerja keras dan memberikan energi serta waktu untuk sebuah pekerjaan (job) atau aktivitas. (Hornby, 2000:242). Bahwa komitmen organisasional merupakan kesungguhan dosen untuk mengabdi bagi UT. Berdasarkan pengertian tersebut, maka komitmen organisasional dosen UT belum optimal, hal tersebut bisa diidentifikasi oleh adanya dosen yang masih enggan untuk terjun dan terlibat ke daerahdaerah tempat pelaksanaan tutorial tatap muka yang dilaksanakan oleh UT.

Terkait dengan hal tersebut, Renstra UT Tahun 2010-2021 halaman 3 menyatakan bahwa lingkungan eksternal yang merupakan lingkungan strategis UT, akan mempengaruhi serta menentukan perkembangan dan pertumbuhan UT dalam upaya menjadi institusi Pendidikan Tinggi Terbuka dan Jarak Jauh (PTTJJ) berkelas dunia di masa yang akan datang. Beberapa faktor lingkungan strategis utama yang mempengaruhi perkembangan UT meliputi: a) Perkembangan dan perubahan strategi ekonomi; b) Perkembangan kondisi sosial politik dan budaya; c) Perkembangan paradigma pendidikan; d) Paradigma baru dan strategi jangka panjang pendidikan tinggi Kementerian Pendidikan Nasional; e) Perkembangan TIK; dan f) Citra publik tentang Pendidikan Jarak Jauh (PJJ). Sedangkan secara umum, faktor internal yang mempengaruhi pengembangan UT pada masa mendatang meliputi aspek: a) Kualitas dan relevansi akademik; b) Daya jangkau dan kualitas layanan pendidikan; dan c) Tata kelola organisasi. Dalam konteks ini, maka manajemen pengetahuan dan komitmen organisasional merupakan salah satu cara dalam meningkatkan kinerja dosen di Universitas Terbuka (UT).

Berdasarkan latar belakang tersebut, maka dapat diidentifikasi beberapa fenomena terkait dengan penelitian ini, antara lain: a) Belum optimalnya kinerja dosen di Universitas Terbuka (UT); b) Naik turunnya kinerja dosen di UT diduga dikontribusi oleh manajemen pengetahuan dan komitmen organisasional yang belum optimal; c) Perlu dilakukan peningkatan kinerja dosen di UT melalui manajemen pengetahuan yang komprehensif serta komitmen organisasional yang optimal. UT membutuhkan data dan informasi empirik dalam meningkatkan manajemen pengetahuan dan komitmen organisasional, yang terkait dengan upaya peningkatan kinerja dosen di UT. Untuk itu, penelitian ini dituangkan dalam tema sentral: "Pengaruh Manajemen Pengetahuan dan Komitmen Organisasional terhadap Kinerja Dosen di Universitas Terbuka (Studi terhadap Persepsi Dosen Universitas Terbuka)".

\section{Kerangka Pemikiran}

SDM perlu dikelola secara baik dan profesional agar dapat tercipta keseimbangan antara kebutuhan SDM dengan tuntutan serta kemajuan organisasi. Keseimbangan tersebut merupakan kunci sukses utama bagi organisasi agar dapat berkembang dan tumbuh secara produktif dan wajar. Perkembangan organisasi sangat tergantung pada kinerja SDM yang ada di organisasi (Veithzal, 2005:7). UT merupakan perguruan tinggi negeri yang melibatkan dosen sebagai ujung tombak dalam kegiatan operasional universitas, sehingga kinerja dosen menjadi sangat penting dan strategis bagi keberhasilan kinerja Universitas Terbuka (UT).

Pengukuran kinerja dosen penting untuk dilaksanakan. Kinerja dosen terlihat dari rasa tanggungjawabnya menjalankan amanah, profesi yang diembannya, rasa tanggungjawab moral dipundaknya. Semua itu akan terlihat kepada kepatuhan dan loyalitasnya di dalam menjalankan tugas kedosenannya di dalam kelas dan tugas kependidikannya di luar kelas. Sikap ini akan dibarengi pula dengan rasa tanggungjawabnya mempersiapkan segala perlengkapan pengajaran sebelum melaksanakan proses pembelajaran. Selain itu, dosen juga sudah mempertimbangkan metodologi yang akan digunakan dalam pembelajaran, termasuk alat media pendidikan yang akan dipakai, serta alat penilaian apa yang digunakan di dalam pelaksanaan evaluasi pembelajaran.

Tjutju Yuniarsih dan Suwatno (2008:161) berpendapat bahwa kinerja merupakan prestasi nyata yang ditampilkan seseorang setelah yang bersangkutan menjalankan tugas dan peranannya dalam organisasi. Kinerja produktif merupakan tingkatan prestasi yang menunjukan hasil guna yang tinggi. Sedangkan Payaman 
Simanjuntak (2005:103) menyatakan kinerja individu adalah tingkat pencapaian seseorang dari sasaran yang harus dicapai atau tugas yang harus dilaksanakan dalam kurun waktu tertentu.

Membicarakan kinerja mengajar dosen, tidak dapat dipisahkan faktor-faktor pendukung dan pemecah masalah yang menyebabkan terhambatnya pembelajaran secara baik dan benar dalam rangka pencapaian tujuan yang diharapkan dosen dalam mengajar. Menurut Kartono Kartini (2005:22), faktor yang mendukung kinerja dosen dapat digolongkan ke dalam dua macam yaitu: faktor internal dan eksternal. Dalam konteks pribadi, kinerja dosen dapat dilihat dari beberapa indikator sebagaimana dikemukakan oleh Noe (2006:260), yaitu: a) Kuantitas pekerjaan; b) Mutu pekerjaan; c) Kemandirian; d) Prakarsa; e) Kemampuan beradaptasi; dan f) Kerjasama.

Untuk meningkatkan kinerja dosen di UT, maka implementasi manajemen pengetahuan dan peningkatan komitmen organisasional dosen menjadi sangat penting dan strategis bagi optimalnya kinerja dosen. UT mengimplementasikan manajemen pengetahuan sebagai salah satu faktor yang dapat menunjang kinerja organisasi. Sebagai universitas yang melaksanakan pembelajaran dengan model pendidikan terbuka jarak jauh (PTTJJ), UT berusaha memenuhi standar penyelenggaraan terbaik PTTJJ yang diakui, baik oleh komunitas maupun lembagalembaga atau asosiasi institusi PTTJJ dunia. Sebagai konsekuensi dan sesuai dengan prinsip sistem PTTJJ, UT juga menghasilkan berbagai produk pendidikan tinggi berkualitas tinggi yang terstandar. Pengertian produk pendidikan tinggi meliputi produk akademik yang secara substansi mengikuti perkembangan ilmu pengetahuan dan teknologi (IPTEK) dan tetap terjaga relevansinya dengan perkembangan masyarakat dan pembangunan nasional; serta lulusan yang kompetitif secara global. Pengertian terstandar adalah kualitas produk yang dijamin baku di setiap tempat penyelenggaraan PTTJJ oleh UT.

UT perlu meningkatkan komitmen para dosennya dalam aktivitas pengembangan organisasi. Dengan adanya komitmen organisasional, diharapkan berbagai tujuan dan program yang telah ditetapkan dalam visi dan misi UT bisa tercapai dengan optimal. Komitmen organisasional (organizational commitment) berhubungan dengan komitmen karyawan terhadap organisasi tempatnya bekerja (Bashaw dan Grant, 1994:41). Menurut Burr dan Ginardi
(2002:80), komitmen organisasional karyawan akan memengaruhi individu untuk mengidentifikasi dan terlibat dalam organisasi, serta rela berkorban untuk kepentingan organisasi. Meyer et. al. (2000:540) dan Hornby (2000:242) menyatakan bahwa komitmen organisasional itu terdiri dari tiga komponen, yaitu a) komitmen afektif (affective commitment; b) komitmen kontinu (continuance commitment); dan c) komitmen normatif (normative commitment.

Keterkaitan antar variabel yang diteliti dapat diidentifikasi berdasarkan dua tahap penting. Pada tahap: (a) pertama, variabel kinerja dosen di UT merupakan variabel yang terpengaruh (dependent variable), sedangkan variabel manajemen pengetahuan dan komitmen organisasional sebagai variabel pengaruh (independent variable) yang berpengaruh parsial; (b) kedua, variabel kinerja dosen di UT sebagai dependent variable, secara simultan dipengaruhi oleh manajemen pengetahuan dan komitmen organisasional. Bertitik tolak dari kerangka pemikiran tersebut, maka dirumuskan bagan keterkaitan antara manajemen kinerja, komitmen organisasional, dengan kinerja dosen di UT, yang dillustrasikan pada Gambar 1 berikut ini: 


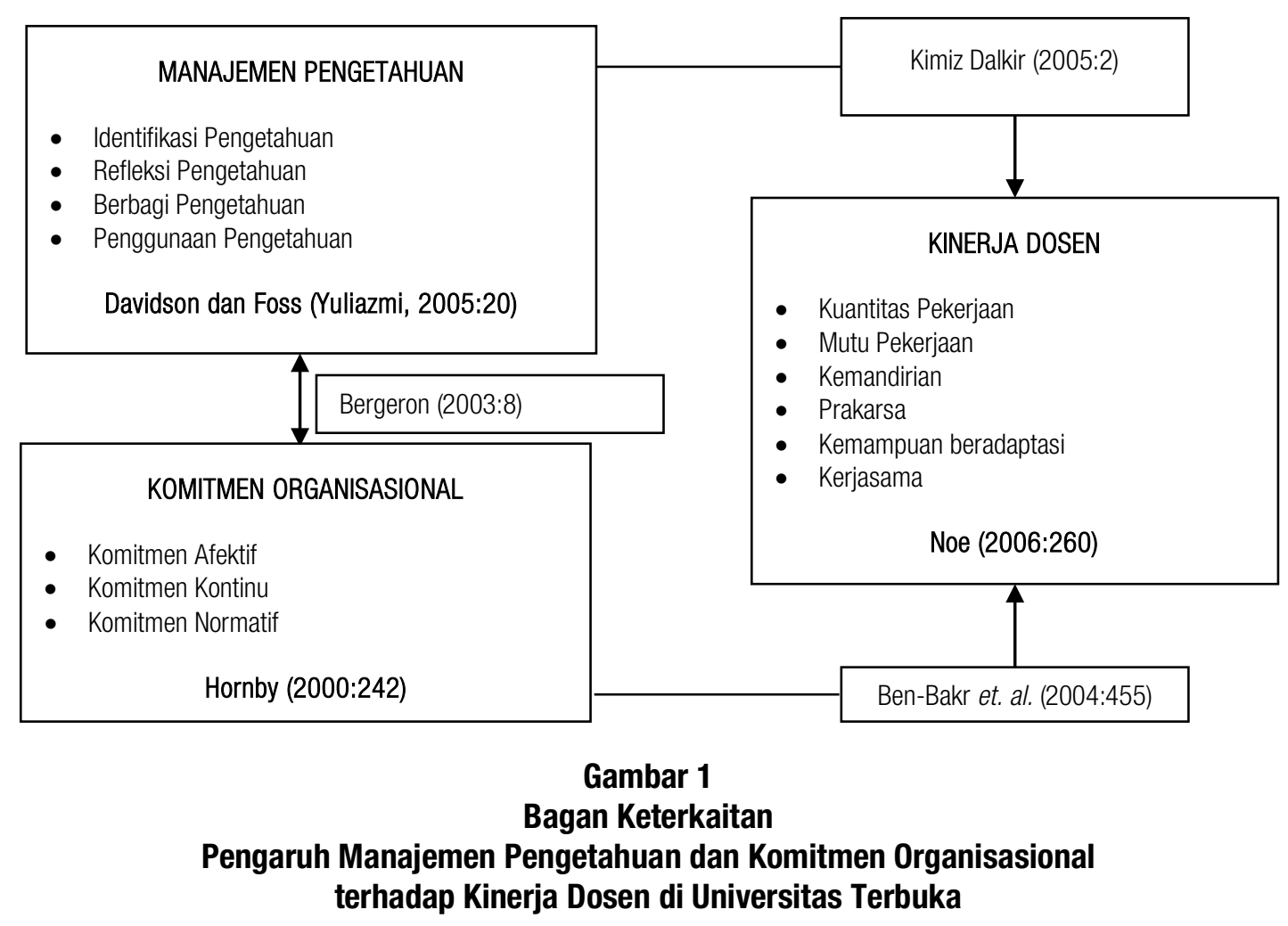

\subsection{Hipotesis Penelitian}

Sesuai dengan latar belakang penelitian, identifikasi masalah, serta kerangka pemikiran yang telah diuraikan sebelumnya, menunjukkan adanya berbagai keterkaitan antara manajemen pengetahuan, komitmen organisasional, dan kinerja dosen. Berdasarkan hal tersebut, maka penelitian ini dirumuskan dalam hipotesis sebagai berikut:

1. Terdapat pengaruh yang positif dan signifikan dari manajemen pengetahuan terhadap kinerja dosen

2. Terdapat pengaruh yang positif dan signifikan dari komitmen organisasional terhadap kinerja dosen

3. Terdapat pengaruh yang positif dan signifikan dari manajemen pengetahuan dan komitmen organisasional terhadap kinerja dosen, baik secara parsial maupun simultan.

\section{Metode Penelitian}

Metode penelitian yang digunakan dalam penelitian ini bersifat deskriptif dan verifikatif. Teknik sampling menggunakan teknik simple random sampling (SRS). Pengujian Reliabilitas menggunakan rumus alpha cronbach, sedangkan pengujian validitas menggunakan rumus korelasi product moment. Karena penelitian ini menganalisis lebih dari dua variabel, maka digunakan teknik analisis regresi linier berganda.

\subsection{Operasionalisasi Variabel}

Terdapat tiga variabel yang dikaji dalam penelitian ini, yaitu: a) manajemen pengetahuan, b) komitmen organisasional, dan c) kinerja dosen. Kedudukan variabel manajemen pengetahuan dan komitmen organisasional sebagai variabel bebas, sedangkan variabel kinerja dosen sebagai variabel terikat.

\section{Tabel 3}

Jumlah Dosen UT per Jenjang Pendidikan pada Setiap Jabatan Fungsional Akademik

\begin{tabular}{|c|l|c|c|c|c|}
\hline \multirow{2}{*}{ No } & \multirow{2}{*}{ Program Studi } & \multicolumn{3}{|c|}{ Pendidikan } & \multirow{2}{*}{ Jumlah } \\
\cline { 3 - 5 } & & S1 & S2 & S3 & \\
\hline 1 & Guru Besar & 0 & 0 & 4 & 4 \\
\hline 2 & Lektor Kepala & 11 & 92 & 16 & 119 \\
\hline 3 & Lektor & 190 & 177 & 4 & 371 \\
\hline 4 & Assiten Ahli & 172 & 41 & 0 & 213 \\
\hline 5 & Tenaga Pengajar & 62 & 18 & 0 & 80 \\
\hline & Jumlah & $\mathbf{4 3 5}$ & $\mathbf{3 2 8}$ & $\mathbf{2 5}$ & $\mathbf{7 8 8}$ \\
\hline
\end{tabular}

Sumber: Universitas Terbuka (2010) 
Tabel 4

Distribusi Sampel per Fakultas di UT

\begin{tabular}{|c|c|c|c|c|c|}
\hline No & Fakultas & Jumlah Dosen & Hitung & Hasil & $\begin{array}{l}\text { Distribusi } \\
\text { Sampel }\end{array}$ \\
\hline 1 & Matematika dan IImu Pengetahuan Alam & 120 & $120 / 788 \times 280$ & 43 & 43 \\
\hline 2 & Ekonomi & 124 & $124 / 788 \times 280$ & 44 & 44 \\
\hline 3 & IImu Sosial dan IImu Politik & 139 & $139 / 788 \times 280$ & 49 & 49 \\
\hline 4 & Keguruan dan IImu Pendidikan & 405 & $405 / 788 \times 280$ & 144 & 144 \\
\hline & Jumlah & 788 & & & 280 \\
\hline
\end{tabular}

Sumber: Berdasarkan perhitungan

\section{Hasil Pengufian}

Tabel 5

Uji F dan Signifikan

Manajemen Pengetahuan dan Komitmen

Organisasional terhadap Kinerja Dosen

\begin{tabular}{|l|c|r|r|c|c|}
\hline \multicolumn{6}{|c|}{ ANOVA $^{\mathrm{b}}$} \\
\hline Model & $\begin{array}{c}\text { Sum of } \\
\text { Squares }\end{array}$ & df & $\begin{array}{c}\text { Mean } \\
\text { Square }\end{array}$ & F & Sig. \\
\hline 1 Regression & $\begin{array}{r}503.507 \\
28349.101\end{array}$ & 277 & 251.753 & 116.509 & $.000^{\mathrm{a}}$ \\
Residual & 102.343 & & \\
Total & 28852.608 & 279 & & & \\
\hline a. Predictors: (Constant), Komitmen Organisasional, Manajemen \\
Pengetahuan \\
b. Dependent Variable: Kinerja Dosen \\
\hline
\end{tabular}

Sumber : Hasil Pengolahan Data 2011

Tabel 6

Koefisien Regresi

Manajemen Pengetahuan dan Komitmen

Organisasional terhadap Kinerja Pegawai

\begin{tabular}{|c|c|c|c|c|c|}
\hline \multicolumn{6}{|c|}{ Coefficients $^{\mathrm{a}}$} \\
\hline \multirow{2}{*}{ Model } & \multicolumn{2}{|c|}{$\begin{array}{c}\text { Unstandardized } \\
\text { Coefficients }\end{array}$} & \multirow{2}{*}{\begin{tabular}{|c|}
$\begin{array}{c}\text { Standardized } \\
\text { Coefficients }\end{array}$ \\
Beta
\end{tabular}} & \multirow{2}{*}{ t } & \multirow{2}{*}{ Sig. } \\
\hline & $\mathrm{B}$ & $\begin{array}{l}\text { Std. } \\
\text { Error }\end{array}$ & & & \\
\hline 1 (Constant) & 88.345 & 5.275 & & 4.813 & .000 \\
\hline $\begin{array}{l}\text { Manajemen } \\
\text { Pengetahuan }\end{array}$ & .259 & .135 & .268 & 3.640 & .000 \\
\hline $\begin{array}{l}\text { Komitmen } \\
\text { Organisasional }\end{array}$ & .482 & .121 & .495 & 4.058 & .000 \\
\hline \multicolumn{6}{|c|}{ a. Dependent Variable: Kinerja Dosen } \\
\hline
\end{tabular}

Sumber : Hasil Pengolahan Data 2011
Tabel 7

Uji Signifikan dengan Perbandingan Nilai

$t_{\text {tabel }}$ dan $t_{\text {hitug }}$

\begin{tabular}{|l|c|c|c|}
\hline \multicolumn{1}{|c|}{ Variabel } & $t_{\text {hituna }}$ & $t_{\text {tabel }}$ & Simpulan \\
\hline $\begin{array}{l}\text { Manajemen } \\
\text { Pengetahuan }\end{array}$ & 3,640 & 1,676 & $\begin{array}{l}\text { Hipotesis } \\
\text { Diterima }\end{array}$ \\
\hline $\begin{array}{l}\text { Komitmen } \\
\text { Organisasional }\end{array}$ & 4,058 & 1,676 & $\begin{array}{c}\text { Hipotesis } \\
\text { Diterima }\end{array}$ \\
\hline
\end{tabular}

Sumber : Hasil Pengolahan Data 2011

Tabel 8

Rangkuman Hasil Analisis Regresi

\begin{tabular}{|c|c|c|c|}
\hline No & $\begin{array}{c}\text { Pengaruh Antar } \\
\text { Variabel }\end{array}$ & Persamaan & Hasil \\
\hline 1 & $\begin{array}{l}\text { Manajemen } \\
\text { Pengetahuan } \\
\text { terhadap Kinerja } \\
\text { Dosen }\end{array}$ & $\hat{\mathbf{Y}}=a+b_{1} x_{1}$ & $\begin{array}{c}\hat{\mathbf{Y}}=67,813+ \\
0,237 X_{1}\end{array}$ \\
\hline 2 & $\begin{array}{l}\text { Komitmen } \\
\text { Organisasional } \\
\text { terhadap Kinerja } \\
\text { Dosen }\end{array}$ & $\hat{\mathbf{Y}}=a+b_{2} \mathbf{x}_{2}$ & $\begin{array}{c}\hat{\mathbf{Y}}=82,067+ \\
0,418 X_{2}\end{array}$ \\
\hline 3 & $\begin{array}{l}\text { Manajemen } \\
\text { Pengetahuan } \\
\text { dan Komitmen } \\
\text { Organisasional } \\
\text { terhadap Kinerja } \\
\text { Dosen }\end{array}$ & $\begin{aligned} \hat{\mathbf{Y}}= & a+b_{1} x_{1} \\
& +b_{2} x_{2}\end{aligned}$ & $\begin{aligned} \hat{\mathbf{Y}}= & 8,345+ \\
& 0,259 X_{1}+ \\
& 0,482 X_{2}\end{aligned}$ \\
\hline
\end{tabular}

Sumber : Hasil Pengolahan Data 2011

Tabel 9

\section{Rangkuman Hasil Perhitungan} Koefisien Determinasi

\begin{tabular}{|c|l|c|}
\hline No & \multicolumn{1}{|c|}{ Pengaruh Antar Variabel } & $\begin{array}{c}\text { Koefisien } \\
\text { Determinasi }\end{array}$ \\
\hline 1 & $\begin{array}{l}\text { Manajemen Pengetahuan terhadap } \\
\text { Kinerja Dosen }\end{array}$ & $17,5 \%$ \\
\hline 2 & $\begin{array}{l}\text { Komitmen Organisasional terhadap } \\
\text { Kinerja Dosen }\end{array}$ & $\mathbf{4 5 , 8 \%}$ \\
\hline 3 & $\begin{array}{l}\text { Manajemen Pengetahuan dan Komitmen } \\
\text { Organisasional terhadap Kinerja Dosen }\end{array}$ & $70,8 \%$ \\
\hline
\end{tabular}

Sumber : Hasil Pengolahan Data 2011 


\section{Pembahasan Hasil Penelitian}

\subsection{Pengaruh Manajemen Pengetahuan terhadap Kinerja Dosen}

Hasil pengujjan F dan signifikansi, dapat diketahui besarnya $F$ hitung melalui uji ANOVA atau $F$ test, yaitu sebesar 80,145 dengan tingkat signifikansi sebesar 0,000. Karena probabilitas 0,000 jauh lebih kecil dari 0,05, maka model regresi ini bisa dipakai untuk memprediksi kinerja dosen atau dapat disimpulkan bahwa manajemen pengetahuan berpengaruh terhadap kinerja dosen. Pengujian signifikansi konstanta dapat dilakukan dengan membandingkan nilai $t_{\text {tabel }}$ dengan harga $t_{\text {hitung, }}$ untuk taraf kesalahan 5\% uji satu pihak dengan $\mathrm{dk}=\mathrm{n}-2$, maka diperoleh $t_{\text {tabel }}$ sebesar 1,676. Karena nilai $t$ nitung lebih besar dari pada $t_{\text {tabel }}(3,644>1,676)$, maka hipotesis diterima. Hal ini berarti terdapat pengaruh positif dan signifikan dari manajemen pengetahuan terhadap kinerja dosen.

\subsection{Pengaruh Komitmen Organisasional terhadap Kinerja Dosen}

Hasil pengujjan F dan signifikansi, dapat diketahui besarnya $F$ hitung melalui uji ANOVA atau $F$ test, yaitu sebesar 87,222 dengan tingkat signifikansi sebesar 0,001 . Karena probabilitas 0,001 jauh lebih kecil dari 0,05, maka model regresi ini bisa dipakai untuk memprediksi kinerja dosen atau dapat disimpulkan bahwa komitmen organisasional berpengaruh terhadap kinerja dosen. Pengujian signifikansi konstanta dapat dilakukan dengan membandingkan nilai $t$ tabel dengan harga $t$ hitung, untuk taraf kesalahan 5\% uji satu pihak dengan $\mathrm{dk}=\mathrm{n}-2$, maka diperoleh $t_{\text {tabel }}$ sebesar 1,676. Karena nilai $t$ nitung lebih besar dari pada $t_{\text {tabel }}(5,055>1,676)$, maka hipotesis diterima. Hal ini berarti terdapat pengaruh positif dan signifikan dari komitmen organsiasional terhadap kinerja dosen.

\subsection{Pengaruh Manajemen Pengetahuan dan Komitmen Organisasional terhadap Kinerja Dosen}

Hasil pengujian $F$ dan signifikansi menunjukkan besarnya $F$ hitung melalui uji ANOVA atau $F$ test, yaitu sebesar 116,509 (lebih besar dari $F$ tabel) dengan tingkat signifikansi sebesar 0,000. Karena probabilitas $(0,000)$ jauh lebih kecil dari 0,05, maka model regresi ini bisa dipakai untuk memprediksi kinerja dosen atau dapat disimpulkan bahwa manajemen pengetahuan dan komitmen organisasional berpengaruh terhadap kinerja dosen. Pengujian signifikansi konstanta dengan membandingkan nilai $t_{\text {tabel }}$ dengan harga $t_{\text {hitung, }}$ untuk taraf kesalahan 5\% uji satu pihak dengan $\mathrm{dk}=\mathrm{n}-2$, maka diperoleh $t_{\text {tabel }}$ sebesar 1,676. Berdasarkan uji signifikansi diketahui bahwa terdapat pengaruh yang positif dan signifikan dari manajemen pengetahuan dan komitmen organisasional terhadap kinerja dosen.

\section{Kesimpulan}

1. Manajemen pengetahuan termasuk dalam kategori yang tinggi. UT merupakan perguruan tinggi yang menerapkan konsep pendidikan jarak jauh, dimana salah satu strategi pembelajaran dalam pendidikan jarak jauh, UT mengembangkan media pembelajaran yang bisa diakses oleh seluruh mahasiswanya.

2. Komitmen organisasional termasuk dalam kategori yang tinggi. UT merupakan perguruan tinggi yang mengusung konsep pendidikan jarak jauh dengan memberikan kesempatan kepada seluruh Warga Negara untuk turut berpartisipasi, sehingga mahasiswa UT tersebar ke seluruh penjuru Indonesia. Hal tersebut perlu didukung oleh komitmen organisasional dosen yang tinggi.

3. Kinerja dosen termasuk dalam kategori yang tinggi. Kuantitas pekerjaan merupakan dimensi yang paling tinggi, sedangkan kemampuan beradaptasi dan kerjasama merupakan dimensi yang paling rendah. Dimana UT berusaha untuk memaksimalkan kinerjanya yang ditujukan bagi peningkatan kinerja UT agar menjadi perguruan tinggi yang unggul dan berkesinambungan.

4. Manajemen pengetahuan dengan kinerja dosen mempunyai hubungan positif yang berada dalam kategori cukup. Manajemen pengetahuan berpengaruh secara positif dan signifikan terhadap kinerja dosen di UT.

5. Komitmen organisasional dengan kinerja dosen mempunyai hubungan positif dan berada dalam kategori kuat. Komitmen organisasional berpengaruh 
secara positif dan signifikan terhadap kinerja dosen di UT.

6. Manajemen pengetahuan dan komitmen organisasional berpengaruh secara positif dan signifikan terhadap kinerja dosen di UT.

\section{Rekomendasi}

1. Refleksi pengetahuan merupakan dimensi manajemen pengetahuan yang memiliki kategori paling rendah. Untuk itu, maka segenap pimpinan dan pengambil keputusan strategis di UT perlu merancang refleksi pengetahuan dengan lebih baik lagi, misalnya dengan melibatkan dosen secara lebih intensif lagi untuk membuat modul perkuliahan, baik berupa buku maupun bahan ajar tutorial online.

2. Komitmen kontinu merupakan dimensi komitmen organisasional yang memiliki kategori paling rendah. Untuk itu, komitmen kontinu dosen di UT perlu ditingkatkan, misalnya dengan cara menerapkan insentif berbasis kinerja (IBK) yang mampu mengikat komitmen para dosen terhadap UT. Dosen yang mengajar di UT perlu diberikan insentif atas prestasinya, sehingga komitmen kontinu dari para dosen akan meningkat. Sistem ini juga diterapkan melalui manajemen kompensasi.

3. Kemampuan beradaptasi dan kerjasama merupakan dimensi kinerja dosen yang memiliki kategori paling rendah. Untuk itu, pimpinan dan pengambil keputusan strategis lainnya perlu untuk mengembangkan mekanisme dan sistem yang memungkinkan para dosen beradaptasi dan bekerjasama dengan mudah terhadap model pembelajaran yang diterapkan di UT. Misalnya dengan melakukan koordinasi melibatkan dosen-dosen yang tersebar di UPBJJ dan kemudian melakukan seminar nasional. Dengan demikian, diharapkan kemampuan beradaptasi dan kerjasama antara dosen dengan lingkungan UT menjadi meningkat.

4. Manajemen pengetahuan memberikan pengaruh yang lebih kecil dibandingkan dengan komitmen organisasional terhadap kinerja dosen. Oleh karena itu, segenap pimpinan dan pengambil keputusan strategis di UT perlu untuk lebih optimal lagi menerapkan manajemen pengetahuan di UT, antara lain dengan menerapkan pembelajaran online terhadap seluruh mata kuliah yang diajarkan, selain itu menyediakan akses bagi para dosen untuk mendapatkan fasilitas dan pelayanan internet yang memadai, memfasilitasi para dosen untuk mentransformasikan pengetahuan tacit menjadi pengetahuan explicit. UT menganut sistem pembelajaran jarak jauh dan terbuka yang mengutamakan aspek kemandirian mahasiswa dalam pola pembelajarannya. Oleh karena itu, apabila UT berhasil mengimplementasikan manajemen pengetahuan dengan maksimal, maka UT akan menjadi perguruan tinggi yang unggul.

\section{Daftar Pustaka}

Any Meilani, 2010. Potret Aktivitas Tutor dan Mahasiswa dalam Tutorial Online Universitas Terbuka (Studi Kasus Program Studi Manajemen-FE). Disajikan di http://www.teknologipendidikan.net

Bergeron, Bryan. 2003. Essentials of Knowledge Management. New Jersey: John Wiley and Son.

Burr, Renu and Antonia Girardi, 2002. Intellectual Capital: More than The Interaction of Competence $x$ Commitment. Australian Journal of Management, Sydney. p. 77-78.

Hornby, A. S., 2000. Oxford Advanced Learner's Dictionary of Current English, $6^{\text {th }}$ Edition. Edited by Sally Wehmeier and Michael Ashby, Oxford: Oxpord University Press.

Kartono, Kartini. 2005. Kepemimpinan: Apakah Kepemimpinan Abnormal itu? Jakarta: PT. Raja Grafindo Persada.

Mohammad Imam Farisi dan Kisyani, 2008. Peningkatan Daya Saing Lulusan Universitas Terbuka (UT) melalui Penyelenggaraan Pendidikan Tinggi Jarak Jauh (PTJJ) yang Berkualitas Internasional. Disajikan dalam Seminar Nasional "Membangun Daya Saing Bangsa melalui PTJJ Berkualitas Internasional". Jakarta, 26 Mei 2008.

Noe, Raymond A. 2006. Human Resource Management: Gaining A Competitive Advantage. New York: Mc Graw-Hill. 
Simanjuntak, Payaman. 2005. Manajemen dan Evaluasi Kinerja. Jakarta: Lembaga Penerbit Fakultas Ekonomi Universitas Indonesia.

Suparman, A. dan Zuhairi, A. 2007. Conflicting Concepts and Implementation of partnership in Distance Education: Seeking New Ideas of Partnership for the Future. Paper presented at the 21st AAOU Conference, Kuala Lumpur 29-31 October 2007.

Veithzal Rivai, 2005. Manajemen Sumber Daya Manusia untuk Perusahaan: Dari Teori ke Praktik. Jakarta: PT. Raja Grafindo Persada.

Yasnimar Ilyas dan Amin Zuhairi, 2004. Pengembangan Sistem Penilaian Kineria Sumber Daya Manusia pada institusi pendidikan tinggi jarak jauh. Jurnal Pendidikan Terbuka dan Jarak Jauh, Vol. 5, No.1, Maret 2004, Hal. 1-18.

Yuliazmi. 2005. Penerapan Knowledge Management dalam Perusahaan Reasuransi: Studi Kasus PT Reasuransi Nasional Indonesia. Jakarta: Tesis pada Magister IImu Komputer Universitas Budi Luhur.

Yuniarsih, Tjutju dan Suwatno, 2008. Manajemen Sumber Daya Manusia. Bandung: Alfabeta. 